Prof. D.H. Sleenberg

Departement Afrikaans-Nederlands

\title{
LITERATUUR EN KULTURELE KONTEKS
}

\section{Konteks}

Dic begrip konteks in verband met die literatuur en die literêre kunswerk in die besonder het al 'n hele geskiedenis en is lank geassosicer met die kontekstualisme van die Amerikaanse New Critics, wat die literêre werk gesien het as 'n "self-contained artefact" (Cuddon 1977:151). Hierdie klemlegging op 'n interne konteks moes 'n romantiese en psigologistiese literatuurbenadering verbreek en het as sodanig 'n goeic doel gedien, egter met die nadecl dat die literẻre werk daarná in toenemende isolasie bestudeer is. Daarom laat ek interne konteks as ' $n$ wins wat reeds verwerf is, links.

Met die oog op die sentrale tema van hierdie simposium wil ek hier 'n denkraamwerk sock en vrae stel in verband met wat Jurij Lotman noem "tekstexterne structuren" (1977:109). Hierdie verbande betrek hy met die oog op die noodsaaklikheid van ' $n$ sisteem van kulturele kodes vir die begrypbaarheid van die teks:

"Daar kommunikasie met behulp van tekens niet alleen een tekst vereist, maar ook een taal, is een kunst werk op zichzelf genomen zonder een bepaald culturele context, zonder een systeem van culturcle codes, vergelijkbaar met 'cen grafschrift in een onbegrijplijke taal"' (1977:107).

Deur die erkenning wat hier aan "culturele context" gegee word, bevestig Lotman die mees wesenlike uitgangspunt van 'n Skrifgefundeerde wetenskap, naamlik dié van geïntegreerdheid van sy objek met ander ervaringsterreine, in teenstelling met die isolasicpraktyk van die outonomisme, dualisme of kontekstualisme van 'n fenomenologiese literatuurbenadering.

\section{Eersle aspek}

Gcen woordkunswerk ontstaan of bestaan in volkome isolasie nic. Dit is 'n unieke taalmaaksel op makrovlak. Op grond van die hoë mate van taalontginning wat dit bevat, fungeer dit as unieke kommunikasiemedium. Daarom sal dit iets bevat van die gemeenskap waarin dit ontstaan het en eerstens bedoel is om begryp te word. Die werk is dus gehonde aan 'n sekere historiese konteks, byvoorbeeld:

- die oorlogsituasie by die ecuwending in ons land (Leipoldt: Oom Gerl verlel);

- die worsteljare van die Afrikaner tussen die twee wêreldoorlö̈ (Van Bruggen: Ampie);

- die laaste strale van die feodale son in Wes-Europa (Cervantes: Don Quijote).

In ooreenstemming met Lotman sou 'n mens kon sê die woordkunswerk ontleen die sisteem waardeur dit kommunikeer, ook aan hierdie aspek van sy konteks. Van hierdie sisteem is die taal die belangrikste komponent maar nie die enigste sistematiese en samehangende gegewe nie. 


\section{Tweede aspek}

'lerwyl die woordkunswerk vanuit 'n historiese konteks ontstaan het, bestaan en kommunikeer dit steeds binne 'n sosiale konteks, waarin die sender konstant bly, maar die ontvanger/leser voortdurend wissel, byvoorbeeld:

- 'n Kleurling lees Kennis van die aund anders as 'n Blanke.

- Elisabeth Eybers se Die ander dors en Marlise Joubert se Klipkus word anders deur mans as deur vroue ervaar.

Sireng gesproke lees geen twee mense dieselfde boek dieselfde nie.

Derde aspek

Enige woordkunswerk van 'n noemenswaardige gehalte raak ook sekere ontydgebonde ervaringsterreine van die mens aan: 'n Droë wil seisoen, met sy sosiopolitiese ervaringsfeer, minder as Magersfontein, o Magersfontein!, met sy betrokkenheid op die historiese, sosio-politiese en estetiese; die oeuvre van byvoorbeld S.V. Petersen minder as dié van Van Wyk Louw; Adam Small se Kanna hy kô hystoe minder as Bartho Smit se Christine. Al is hierdie werke samehangende eenhede, toon hulle verskille as die ervaring wat daarin vervat is, vergelyk word met die spektrum van ervaring wat onderskei word volgens denksisteme soos die wetskringe van Dooyeweerd of die Dieptesielkunde of in die onderskeie mitologieè. Hier is dit nie tyd wat 'n rol speel nie maar universaliteit. In aansluiting by die vorige kan 'n mens sê:

* Sekere teoloë lees Magersfontein, o Magersfontein! anders as die meeste literatore.

- 'n Sosioloog sal dit weer anders lees as 'n historikus.

- I.inkse en regse politici sal Breytenbach se werk verskillend lees en wel nóg anders as die meeste literatore.

Vervolgens elk van hierdie aspekte van kulturele konteks van nader beskou:

\subsection{Historiese konteks}

\subsubsection{Tydkonteks/tydgees / lewenstyl/konfigurasie/concurrence / diaposon/patlern of culture}

Francis Bacon het al in 1605 die literêre 'gees' van 'n tyd geknoop aan styl en werkwyse (metode) van die literatuur (Kamerbeek, 1964:191). Die begrip tydgees, wat sedertdien dikwels verwoord is, berus daarop "dat de voortreffelijkste geesten in elke tak van kunst en wetenschap (telkens) in dezelfde nauwe tijdsruimte samenvallen en in dezellde trant werken" (Kamerbeek, 1964:191).

Met "trant" word hier ook na jets soos "cultural codes" verwys. Die begrip berus dan op die beginsel van 'n eenheid te midde van die veelheid van gelyktydige verskynsels (Kamerbeek, 1964:209), en dit het betrekking op meer as die literatuur, ook op die wetenskap, na my mening op die kultuurkonteks in die geheel, wat verander soos die gemeenskap en sy lewensomstandighede verander. Dit blyk dat ons eie bevolking, en die Afrikaner in die besonder, sedert Wêreldoorlog 11 'n redelik drastiese verandering van tydgees belewe het, waarskynlik op die spoor van wat in Europa gebeur het. Dit is nóg 'n stadium in 'n lang ontwikkelingsgang in die 
Soos in die Nuwe Roman nou eers 'n terugflits om hierdie ontwikkelingsgang kortliks aan te toon:

'Tot min of meer die 5de eeu v.C. kan gepraat word van 'n primitiewe fase in die kuns, gekenmerk deur 'n mitologiese wêreldbeeld. Die oormag van die natuurgeweld is byvoorbceld die hoof gebied met ' $n$ mimesis of gelykmaking van dic kunstenaar aan die natuurgegewe (of nie-ek) om só die difluse (chaos) te verdring. Iets hiervan leef in die handeling van die primit iewe mens in Eugène Marais se Die dans van die rë̌n. Hier is kuns en godsdiens nie te skei nie, en by pimitiewe volke bestaan hierdie fase vandag nog voort. Maar 'n kunslose toestand is vir die mens net so ondenkluaar as 'n woordlose bestaan.

In die feodale ontwikkelingstadium (5de tot die 11 de eeu n.C.) dra die kuns die las van diensbaarheid aan die kerklike en wêreldlike mag (Wolandt 1972:196). Die finale bevryding van die mag van buite vind eers in die 18de eeu plaas - 'n aanduiding van die uit werking wat die verknegtheid van die skrywer op die kuns het. In die feodale tydperk is daar nog vervaging van grense tussen letterkunde en wetenskap en tussen kuns en werklikheid. So word werklike avonture van Karel die Grote aangedik tot fiksie (rondom die 9de eeu).

1605, die jaar van die verskyning van Cervantes se roman Don Quijote, kan gesien word as die aanvang van die burgerlike fase in die ontwikkeling van die literatuur. Dit word gekenmerk deur die emansipasie van die kunstenaar omdat die kerk- en hofdiens nie meer vir hom vooropstaan nie. Kunsvoortbrenging word 'n burgerlike 'beroep', 'n saak van die enkeling vir die enkeling, met al die voordele en risiko's wat daaraan verbonde is. Een daarvan is dat die kuns mark toe gaan, en dat die skrywer 'vir die volk' skryf, sodat die aanvraag van die opkomende burgery die gehalte van die kuns begin bepaal. Die oppervlakkige kyk van die gemeenskap word norm vir die literatuur. Dit is egter dic einde van 'n pad. Die optiese periode, soos dit al genoem is (Leber, 1966:418), bereik 'n hoogtepunt in die neerslae van die positivisme in die kuns, naamlik die naturalisme en die realisme. Dit word gekenmerk deur 'n veruiterlikingstegniek, soos in die sosiale dramas en sosiale prosa van byvoorbeeld Gerhart Haupımann en Louis Couperus respektiewelik. Beelding vind van buite, net vanuit een perspektief plaas.

Hoewel daar in die laat $19 \mathrm{de}$ eeu nog geskryf is vanuit die omvattende (uiterlike) herkenbare, stel Hugo Leber dit duidelik dat, as dit in die twintigste eeu moet gebeur, dit net ' $n$ halwe waarheid sal wees (1966:418). Met dic ceuwending verskuif die blik van die Europesc kunstenaar van buite na binne. Die binnewêreld van die mens word nou hoofinhoud van die woordkunswerk, met ooreenstemmende implikasies vir die tegniese struktuur en die begrypbaarheid daarvan. Met die drastiese vooruitgang op natuurwetenskaplike gebied, veral gekenmerk deur die Relatiwiteitsteorie van Albert Einstein (1904) verloor die werklikheid sy oorskoubaarheid en besef die denkende waarnemer dat wat hy ervaar, net 'n onscker fragment van die geheel kan wees. Die wêreld van die woordkunswerk word dus in 
ooreenstemming hiermee steeds ingewikkelder, en dit geld veral die drama en die prosa: in Afrikaans breek hierdie verandering eers na die helfte van die eeu, na volle onathankliheid van die Afrikanerrepubliek, deur. Tyd-en werklikheidsvlakke word in prosa en drama deurbreek. Die parallelle belewing van hede en verlede in Bartho Smit se Christine sou onwaarskynlik wees in die burgerlike (dikwels sosiale) drama van die vorige fase in die kuns. Die verhoor wat daarin plaasvind, gee gestalte aan 'n selfondersoek, soos die verhoor in Brink se drama met dié titel uitdrukking wil gee aan 'n herondersoek van die geskicdenis. Werklikheidsvlakke vervloei dus. In die prosa is dit merkbaar in die roeringe rondom die verteller, in Afrikaans tot op hede die verste gevorder in Mahala (Chris Barnard), Magersfontein, o Magersfontein! (l.eroux) en Gerugte van reën (Brink). Die subjektiewe betrokkenheid in die poësie van Breyten Breytenbach en D.J. Opperman in sy Komas uit 'n bamboesstok is 'n bevestiging van wat inderdaad in die prosa en drama so konkreet gebeur het: 'n kyk na binne, met al die implikasies wat dit vir die begryp van die woordkunswerk het. Terselfdertyd bring hierdie subjektiewe betrokkenheid mee dat eksterne verbande nouer by die teks betrek word, soos die biografiese besonderhede van die digter.

Nog 'n belangrike gevolg van die einde van die realisties-positivistiese wêreldbeskouing en die doodbloei van die literatuur van die uiterlike is dat skrywers in opstand kom teen die minderwaardige rol wat die literatuur in die burgerlike fase gespeel het. Die burgerlike literatuur het so deursigtig en vanselfsprekend geword dat dit onopsigtelik geword het. In die relativistiese tydkonteks wil skrywers elke werk 'n gebeurtenis maak. Ongelukkig bring dit ook mee dat die woordkuns 'n nabygeleë oogmerk kry, wat 'n vervlakkende uitwerking het. Dit hang nie net saam met die politieke betrokkenheid in die prosa en drama soos geînisieer deur Camus en Sartre nie, maar ook die invoer van skoktegnieke. Hieronder ressorteer seker ook berekende aanwending van vierletterwoorde. Met hierdie opstand verdien hierdie literatuur die benaming anti-burgerlik.

Sekerlik kan hierdie tydgees kuns oplewer soos enige ander, maar dit bring 'n andersoortige kommunikasiesisteem vir die kuns mee en waarskynlik 'n ander siening van die kuns. Dié sisteem is nie gebaseer op die uiterlike, vanselfsprekende nie maar op die bewussyn van die ingewikkeldheid en relatiwiteit van die werklikheid. Lesers wat nog nie die "trant" van hierdie woordkuns bemeester het nie, sal noodwendig gebrekkig met hierdie werke kommunikeer of hulle selfs verwerp.

\section{I.2 Die akluele werklikheid}

F.G. Droste (1980:348), wat skryf oor die werklikheidsgehalte van die literatuur, sê "dat werklijkheid een intellectueel begrensd kader is, een begrip waarvan de grenzen getrokken worden door hel overleg binnen een culturele gemeenschap". Dinge, sake en gebeurtenisse kry hulle betekenis binne 'n sekere kulturele konteks, waarin die tydgees meespreek. Die werklikheid waaruit 'n skrywer put by die voortbring van sy werk, is dan meer as die hier en nou of, soos Droste dit stel, meer as die "lavoriete wereld". Baic radikaal stel hy dit so: "Het zijnde is geen werkelijkheid maar wordt tot werkelijkheid gemaakt in de orde van de ervaring" (1980:350). Al sou 'n mens nie sy hele redenasie volg en aanvaar nie, is dit aanduiding van die 
primêre rol wat ervaring van die fisieke werkliklıeid by hierdie aspek van 'n kunswerk - naamlik die werklikheid waaruit dit voortkom - speel.

Van skrywers van die nouveau roman (Butor, Sarraute, Robbe-Grillet, Claude Simon) sê Hugo Leber dat hulle uit subjektiewe ervaring 'n kunswerk bou (1966:423), en dit stem in 'n groot mate ooreen met die aanbod van literatuur in ons eie tyd en situasie teenóór die objektiewe gemeenskapsvisie op die fisieke werklikhcid wat deurslag gegee het by die ontstaan van ouer Afrikaanse prosawerke; hoewel daar 'n polemiek gevocr is oor Ampie van Van Bruggen.

Elke kulturele werklikheidskonteks wat so gevorm word, lewer sy eie ervaringskerne of probleemkerne vir die denker, en van alle ervaring kan kuns gemaak word:

- 'n besondere mensbeeld, soos dié van die buitestaander, wat in talle prosawerke, ook in $\Lambda$ frikaans, beslag kry: byvoorbecld van Jan Rabie, Dolf van Niekerk, Etienne Leroux, John Miles, Karel Schoeman;

- die probleem van die ongelykheid van mense (Brink, Schoeman);

- omstrede beeld van die Afrikaner (Rabie);

- die verskeidenheid en uitwerking van die sonde (Anna M. Louw);

- geweld (P.J. Haasbroek);

- die probleem van vernuwing (Etienne Leroux).

Soos ' $n$ joernalis besluit wat nuuswaardig is, selekteer die skrywer bewus of intuïtief wát uit 'n bepaalde konteks uiteindelik tot kuns verwerk word: die digter waarskynlik die gegewe met die meeste duidingsmoontlikhede, die dramaturg dié met die meeste spanningsmoontlikhede, en die prosaīs dié met die meeste gebeuremoontlikhede, hoewel elke woordkunswerk uniek is. Dit is egter wanneer die skokkendste vir die literatuur gekies word, dat 'n mens begin twyfel aan die kunswaarde van 'n sekere seleksie, soos die beskrywing van die lyding van die voorgeslagte van Josef Malan in Kennis van die aand. Maar dan: Lê die rede vir hierdie toedrag van sake nie in die kulturele konteks nie?

Dit kan gebeur dat 'n tema byna of geheel ontbreek in 'n sekere tydvak, soos die rasseproblematiek hoofsaaklik afwesig is in die prosa van die vroee Sestigerjare. Die enigste twee Afrikaanse prosaiste wat hulle in daardie periode aan die probleem van volkereverhouding gewaag het, was.Jan Rabie en Elsa Joubert, slegs met Ons wag op die kaptein as winspunt. Die ander prosaîste lê hulle in dié tyd toe op 'instrumente slyp' rondom die tema van soeke na die self.

Dit is al genoeg aanduiding dat die aktuele werklikheid en die seleksie daaruit nie objektiewe aangeleenthede is nie. Daarom kan ook nie verwag word dat die uiteindelike produk 'n objekt iewe gegewe moet wees nie. Vir die begryp van die literere werk beteken die verskil in werklikheidsvisie tussen skrywer (werk) en leser 'n kommunikasiebreuk, wat vervremend werk of selfs volkome verwerping van die werk kan meebring.

Objektiwiteit in die literêre werk gaan uiters so ver soos die historiese verwysings, byvoorbeeld (implisiet) na die koerantberig waarop Ons wag op die kaptein gebaseer is, 
na die ondergang van die aringa waarop Bonga teruggevoer kan word, die lerse opstand in die 18de eeu in Karel Schoeman se By fakkelligen die Hitler-era in Bartho Smit se Christine. Slegs die tydsituering is dan geknoop aan objektiewe historiese feitekennis, hoewel ook dit in Magersfontein, o Magersfontein! as ervaring opgeroep word. En dan: ls die geskiedenis 'n objektiewe gegewe?

Om saam te vat: die ervaring van die historiese konteks van 'n literêre werk is nie 'n objekt iewe gegewe nie, want alles wat 'n mens ervaar, word lewensbeskoulik gekleur. Dit geld veral die tyd waarin ons leef, skryf en lees!

\subsection{Sosiale konteks}

Die literêre werk is lank beskou as st ruktuur, dit wil sê vanuit fenomenologiese hoek. Selfs André P. Brink (1980:7) spreek nou sy bedenking uit teen die fenomenologiese kompartementering van die kunswerk, waardeur die literatuur losgemaak word uit die lewe. Die literêre werk word ál meer opgeneem as unieke kornmunikasieeenheid, wat tot stand gebring word tussen 'n geimpliseerde outeur en onbekende leser(s) binne 'n kulturele kontcks. Oındat dit op unieke wyse verhoudinge impliseer, kry die funksie van die literêre werk daardeur 'n sosiale kant: dié van 'n ingewikkelde teken in die kommunikasieproses tussen skrywer en leser/gemeenskap. In hicrdie sosiale konteks is daar verskeie belanglebbendes, wat dringend ons aandag verdien.

\subsubsection{Die skryuer}

Die skrywer is die belangrikste liguur in die literêre kornmunikasieketting omdat hy die maker van die produk is, of die kommunikasieproses inisieer. Uit wat reeds gesê is, is dit duidelik dat die tydgees in ons bedeling meebring dat die skrywer die ' werklikheid anders sien as wat dit die geval was in die 19de eeu en in ons eie ouer literatuur, in besonder die prosa. Daarteenoor kon een van die volgende met die leserskorps gebeur het:

- Die verskuiwing in werkliklıeidsbenadering kon ongemerk by hulle verbygegaan het.

- Dit het moontlik nic tot die unassa deurgedring dat die literatuur in ooreenstemming met so 'n verskuiwing ook anders sou moes lyk nie.

Bowendien skryf die skrywer in die konteks waarin Afrikaanse werke nou geskryf word, met 'n bepaalde beklemming:

Die cerste beklemming spruit voort uit die mag van die massa, in dié sin dat fétlik enigiets opspraakwekkends in ons bedeling gebruik kan word vir geldelike gewin. Opspraakwekkende prulwerke en louter pornografie verdring as gevolg van die demokratisering van skrywerskap maklik die goeie, dikwels moeiliker, literêre werk. Skrywers van beter, emstige, eerlike kuns moet met sulke werke kompeteer om enigsins die kalklig te steel. Brink (1980:11) sê saam met Sartre: "Die skrywer sktyl sodat hy 'n beroep kan doen op dic vryheid van sy lesers, wat hy nodig het om sy werk te laat bestaan'. In 'n konteks waarin daar min aanvraag vir die literêre werk en meer vir die goedkoop prulwerk is, het die skrywer 'n wesenlike dilemma. Of die 
literatuur gaan ongemerk verby, of dit word oppervlakkig kontensieus, met nadelige gevolg vir én literatuur én gemeenskap.

Verder ly die skrywer onder die politieke druk waarin die land verkeer. Omolat die Staat van buite bedreig word, sal enige publikasie wat 'n teken van bedreiging vir gocic orde en goeie verhoudinge inhou, begryplikerwys met ' $n$ vergrootglas dopgehou word. Dit, en selfs die moontlikheid dat 'n manuskrip gesensureer kan word, is nie bevorderlik vir' $n$ kommervrye beofening van die woordkuns nie. Twee stellings van Anna M. Louw (Beeld, 27.Januarie 1981:9) gee aanduiding hiervan:

"' $n$ Vorm van sensuur is nodig om pornografiese stof en opruiende politieke materiaal uit die land te hou. Die letterkunde word ook soms om politieke redes misbruik"

en

"Uit cie ervaring weet ek watter bittere, censame taak dit is om 'n roman voort te bring. Dit bedruk 'n mens om dan by ' $n$ verbod daarop betrokke te wees".

Niemand in Suid-Afrika kan die gevaar van buite wegdink nie. Dus is daar min aan so' $n$ gevoel van bedreigdheid by die skrywer te doen. Of moontlik baie? Dit is in elk geval nodig dat die waarde van die letterkunde so wyd moontlik besef word. Kan die Departement Kultuursake nic aandag gee of laat gee aan die waarde van die letterkunde en die posisie van die skrywer in ons samelewing nie? Ek vrees die intreerede van André P. Brink verlede jaar in Grahamstad is nie genoeg nie. En kan onderwysdepartemente nie 'n verrykte kursus in kreatiewe skryfwerk aan begaafde leerlinge onder hulle sorg gee nie? En wat van kursusse in kreatiewe skryfwerk op universiteit?

\subsubsection{Die woordkunswerk in konteks}

Wat is die afstand tussen woordkunswerk en konteks? Daarmee het die taal baie te docn. F.G. Droste formuleer reeds die werklikheid in terme van ons taalbewussyn: "Werkelijkheid is een veld dat door ons taalbewustzijn met het daarvan afhanklijke denken afgebakend wordt" (1980:347).

Dit sluit vir hom dinge en stelsels en tye in. Die literêre werk is 'n unieke manier om jou wêreld in taal te begrens, intuitief te ken, te toets en toe te eien. Deur die middele en momente van die woordkunswerk word ondefinieerbare ervarings binne 'n sisteem of patroon vasgelê en só vir die skrywer self of sy leser hanteerbaar gemaak anders sou hulle aan die chaos van hulle wêreld oorgelewer gewees het. Só kry die literatuur waarde in soverre dit die "versplinterde wêreld", soos Brink (1980:10) dit uitdruk, integreer in 'n vatbare taalpatroon, waarin verbande tussen woord en lewenservaring gevind word. Dink maar aan die onthullende spel van lig en donker in die poësie en versdramas van N.P. van Wyk Louw; die bociende aardse simbool in die poësie van D.J. Opperman; die visuele in die prosa van Hennie Aucamp en die singewende kruisigingsmotief in Christine van Bartho Smit. Die skrywer laat met sy medium die leser opnuut na sy bekende wêreld kyk en verryk hom deur verbande te onthul wat hy nie voorheen raakgesien het nic. In 'n klandestiene geskrif uit die 
Tweede Wêreldoorlog ken Ernst Wiechert 'n heleude funksic aaı die literatuur toe. Die skrywer moet volgens hom "die wonde van sy tyd" (van sy konteks) aanraak om liulle te genees. Dit moet hy doen deur te onthul:

"was in Welt verdunkelt und oft geschändet ist: die Wahrheit, das Recht, die Freilıeit, die Güte, die Liebe und über allem den Sinn und das Gesetz einer grossen Weltordnung" (1945:24).

Dit stem ooreen met Cassirer se siening van die kuns as "a revelation of a genuine aspect of our life" (Wimsatt 1957:702).

Die taal met sy ordenende struktuur word die grens tussen werklikheid en literêre werk. Tussen die twee bly daar egter tóg steeds verbande. Brink (1980:15) verwys na Toynbee se begrip van "withdrawal and return" wat tussen konteks en kunswerk plaasvind - 'n wegbeweeg van die werklikheid aan die begin van die werk en 'n terugkeer daarheen aan die einde. In Chris Barnard se Mahala voer die aankondiging van die vrees van die hoolkarakter in die eerste paar reëls die leser weg uit die werklikheid na die sfeer van die kunswerk, terwyl die konfrontasie met die son in die slot hom weer aan die werklikheid uitlewer. Soos die taalstiuktuur van die woordkunswerk dus kommunikasiemedium is tussen implisiete outeur en leser, is dit ook 'n ompad uit die werklikheid na die werklikheid.

Dit is belangrik dat literêre tekste ook weer deel word van die kulturele konteks waarin hulle ontstaan en voortbestaan. Inderdaad is 'n literêre werk een van die mees verfynde produkte van die mens se ontginning van die skatte van die kosmos. Só word dit imners tradisioneel gesien as 'boek' met 'n terminale aard, as teks met 'n bepaalde voorkoms, samestelling en opset, wat by lees en herlees in 'n ander tydkonteks as dié van sy ontstaan gedekodeer of gerealiseer word, soos dit soms heet. Vondel se dramas is dan kultuurskatte wat steeds terugverwys na die kulturele konteks van die Nederlandse $\mathrm{J} 7 \mathrm{de}$ eeu en trouens teen daardie agtergrond gelees moet word.

Die woordkunswerk word dus ook weer deel van die theatrum Dei van 'n volgende kunstenaar, net soos 'n skrywer en sy hele oeuvre dit ook kan word. Dic wêreld van C. L. Leipoldt word werklikheid (stof) vir '" prosawerk van Karel Schoeman (Die reisiger) en 'n drama van Henriette Grové (Ontmoeting by Dwaaldrif); sy gedig 'Boggom en Voertsek' verskaf materiaal vir die Oppermangedig met dieselfde titel. So groei kultuurkonteks en kunskonteks ook saam in die gedig-oor-die-gedig en verhaal-oordie-verhaal, soos Etienne Leroux se Isis Isis Isis en Henriëtte Grové se Vakansie vir 'n hengelaar: by die ontstaan van dié werke word hulle onmiddellik deel van hulle eie kultuurkonteks. Die wêreld van die mens D.J. Opperman word betrek binne die gedigte in Komas uit 'n bamboesstoh. Ek meen dit is onder andere aanduiding van 'n strewe om die literatuur binne die volle lewe te plaas.

Belangrik is dat die woordkunswerk ervaring van die outeur is wat vasgevang is in 'n woordbouwerk - 'n unieke geheel met 'n eie geïntegrecrde visie. 


\subsubsection{Die leser}

Hierdie belanghebbende by die literêre werk het eintlik in 'n groot mate die wel en wee van die literatuur in sy hand. Eerstens is dit die leser wat uiteindelik die potensiaal van die teks ontgin deur te lees en te ervaar. Die ontsluiting van 'n teks wissel eintlik van soort leser tot soort leser en selfs van persoon tot persoon.

Die sogenaamde waarskynlike leser en sy omskrywing is van dringende belang by beoordeling van 'n werk deur die Sensuurraad. Die feit dat dit die strewe van regsverteenwoordigers is om hierdie begrip so eng moontlik te formuleer, is egter 'n ironiese erkenning van die beperktheid van die omvang van die betrokke werk se leserskring en dus van sy invloed: ironies omdat iemand wat die literatuur wil bevorder deur die vrystelling daarvan te probeer bewerkstellig, juis die onpopulariteit of in 'n sekere sin sy 'onleesbaarheid' probeer bewys.

Die geïntendeerde leser of ideale leser is 'n abstrakte begrip, wat volkome instemming en begrip tussen teks en leser impliseer. Dit is egter'n ideale toestand wat net van 'n beperkte aantal ontmoetings tussen teks en leser geld.

Maar daar is 'n baie groot kloof tussen die Afrikaanse literatuur en 'n groot aantal werklike lesers en sluiplesers.

Met sluiplesers bedoel ek daardie lesers wat eers 'n sensasicwekkende koerantberig oor 'n omstrede werk lees en dan die werk gedeeltelik of geheel lees op soek na omstrede passasies. Or hierdie sluiplesers verlustig hulle op 'n heel onestetiese of onetiese wyse in hierdie fragmente wat ook in die werk verwerp word, of die fragmente word uitgelig om die werk verbied te kry en uit die eerste groep se hande te hou. Dit bly die grootste beswaar teen die betrokke juridiese prosedure dat 'n sluipleser se klag kan meebring dat 'n literêre werk van redelike of aansienlike gehalte verbied kan word, soos vermoedelik met Magersfontein, o Magersfontein! gebeur het. Die nadeel van eensydige leesaktiviteit is ongelukkig dat dit deur herhaling gevestig word en lei tot verdagmaking van die literatuur. Natuurlik bepleit ek nie die gebruik van omstrede woorde in die woordkunswerk nie - net vir die crkenning van die literêre werk as unieke sfeer met 'n eie waardesisteem. Ongelukkig is hier ook ' $n$ bose kringloop aan die gang, naamlik van sommige skrywers se opstand na die opstand van sekere lesers, na implementering van die mag van die Staat, na opstand van nóg meer skrywers!

Hiermee saam hang die afstand tussen skrywer en kerk, waarvan Phil du Plessis (p. 19) en ander digters in Standpunte 150 praat. Hy pleit vir die reg van die digter om sy twyfel ook oor God uit te spreek - iets wat hy meen by die verwerping van Breytenbach se Onse milde God deur J.A. Heyns ontken is. 1.L. de Villiers praat van aanpassingsprobleme van die Kerk en dat Kerk en kunstenaar mekaar oor en weer respektiewelik as libertyne en Puriteinse suurknolle beskou (Standpunte 150:8). Aan die wortel van hierdie geskil lê 'n sekere tekortkoming, waarskynlik by elk van die betrokke partye, en ek meen dit kan teruggevoer word na die kompartementering van die wetenskappe deur outonomiste. Dit ontbreck nog aan die volgende: 
- 'n goed geformuleerde en breed aanvaarde eie standpunt by verteenwoordigers van die Geïnstitueerde Kerk wat hulle op hierdie terrein begeef;

- 'n grondige kennis van die werking van die literatuur by sommige persone wat hulle op die terrein van die literatuur begeef.

Beoefenaars van die woordkuns is daarteenoor soms geneig tot verabsolutering daarvan.

Gesprek tussen kerk en skrywer, soos reeds plaasgevind het, is verblydend, en in so 'n gesprek moet albei partye geslyp word. En bowe al: Die Kerk moet sy taak van woordverkondiging uitvoer en hom weerhou van voorskriftelikheid. En sou kennis van die literatuur en sy werking, wat inderdaad op die weg van die teoloog as kenner van die literatuur van die Bybel lê, nie mérér onder aspirant-predikante bevorder kan word nie?

Die literator is 'n baie prominente belanghebbende leser in die literêre situasie. Wat die uitkoms van hierdie krisis in die estetiese lewe van die Suid-Afrikaanse gemeenskap sal wees, hang in 'n baie groot mate van hom af. En sy hantering van die probleme hier rondom hang af van die begronding van sy literatuurteorie, waarvoor die volgende van belang is:

- Die fenomenologiese benadering van die kontekstual isme en strukturalisme met die mite van die selfgenoegsaamheid van die teks soos dit voortkom uit die positivisme, het, ten spyte van winste, misluk, soos die Victoriaanse etos met sy dualistiese wêreldbeeld misluk het.

- Geisoleerde teksstudie in 'n ivoortoring lei net tot fragmentering van die ingewikkelde werklikheid van ons tyd. Literatore het 'n taak om ook met die gemeenskap in gesprek te tree oor hulle studieobjek, in samehang met ander lewensterreine.

- Die woordkunswerk kan eers ten volle tot sy reg kom as dit bestudeer word as gelintegreerde eenheid binne die hele spektrum van ervaringsfere.

- Partyskappies onder literatore en venynige persoonlike aanvalle op mekaar in die openbare pers maak die literatuur en literatuurstudie verdag.

Verder is dit ongelukkig so dat die klaskamer die belangrikste plek vir die 'verkoop' van die Alrikaanse letterkunde bly, al is dit so dat die aantal studente wat die literatuur bestudeer, waarskynlik daal. Dit maak dit so veel dwingender dat leerlinge op skool reeds 'n goeje geesteswetenskaplike vorming, waaronder literatuurkundige vorming, behoort te kry. Daarvoor is die vak Afrikaans en Engels Eerste Taal ongelukkig te veel oorlaai. Dit het nodig geword dat basiese Lees-, spel- en Kommunikasiconderrig (begripstoets of teksstudie) ' $n$ afsonderlike vak in die junior hourskool word sodat 'Taal-en Literatuurwetenskap onder die koepel van Afrikaans en Engels tot hulle reg kan kom. So kan 'n noodsaaklike breër kundigheid oor kommunikasie gebou word tot voordeel van die vorming in elke vak in die hoërskool. Die voordeel daarvan vir die 'laal-en Literatuurwetenskaplike vorming van leerlinge is vanselfsprekend, want so kan die gaping op hierdie belangrike ervaringsgebied in ons materialistiese samelewing gevul word. 


\subsection{Universple konleks}

André P. Brink praat in sy intreerede van die 'versplinterde wêreld' waarin die funksies van wetenskaplike, opvoeder, priester, storieverteller en filosoof skaars meer raakpunte vertoon. Dan noem hy die literatuur "cen van die oorblywende streke waar die uiteenlopende en die verskillende nog met mekaar in verband gebring kan word en aan die mens verbind kan word" (1980:13). Dit is terselfdertyd eintlik 'n cvaluerende stelling: Só is goeie literatuur. L. Yntema verwerp al in 1945 (:190) vanuit die standpunt van die Neo-Calvinisme elke soort monisme, ook die pistiese monisme, dit wil sê eensydigheid en ook religieuse eensydigheid, in die literatuur. Daarteenoor bepleit hy 'n "pluralistisch prosa, waarin bovendien de verschillende wetskringen in hun natuurlijke volgorde worden erkend, het grenskarakter der geloofsfunctie geërbiedigd en de sinvolheid der werkelijkheid in het boventijdelijke gezocht" (1945:190). Sy ideaal is "kosmiese veelheid" en "artistieke eenheid", wat natuurlik eerstens 'n norm vir goeie kuns is. Maar dit is ook 'n gesonde uitgangspunt vir die benadering van die literêre werk, vir samewerking tussen die wetenskappe. Met erkenning van die werkwyse van die literêre werk kan literator, teoloog, sosioloog, historikus, psigoloog, etikus, taalwetenskaplike, ensovoorts, mekaar binne die literère werk ontmoet, en so die vyfduisend met die visse van die kunswerk as kultuurskat voed, soos Ernst Wiechert (1945:14) dit uitdruk. Op hierdie wyse kan die onmisbare wisselwerking tussen literator en geesteswetenskaplike oor die algemeen plaasvind, en kan skrywer en predikant en skrywer en wic onk al die gesprek voer wat die literêrc werk eintlik is en vereis.

Die konteks waarin Afrikaanse woordkunswerke in ons tyd ontstaan en fungeer, is só besoedel met absolutisme, dualisme, isolasionisme, monisme en selfs bombasme dat dit seker kwalik binne een geslag opgeruim kan word. Miskien moet hierdie geslag eers verbygaan voordat die gesprek rondom die literatuur sinvol gevoer kan word.

Dit het dringend nodig geword om nie net te verseker dat goeie werke in Afrikaans ontstaan nie maar ook dat weĕ gevind word om hierdie belangrikste kultuurskat naas die godsdiens in ons volkslewe tot sy reg te laat kom. En daar is haas mee. Die tyd loop uit.

\section{BIBLIOGRAFIE}

(Waarna verwy" word en vir verdere leeswerk)

ADORNO, T.W. 1965. Engagement. (In sy Noten zur Literatur, III, Frankfurt). ANEMA, Seerp. 1926. Moderne kunst en otaarding. Kampen, Kok.

BARNES, Hazel E. 1950. The literature of possibility. Lincoln, University of Nebraska.

BAR TH, John. 1969. The literature of exhaustion. (In The American novel since World War II, ed. Marcus Klein. Greenwich, Conn., Fawcett Publications). BOMHOFF, J.G. 1967. Theologie der literatuur. Vox Theologica, jg. 37:118-132. BOMHOFF, J.G. 1969. Evangelie en literatuur. (In: Grensgesprekken. Kampen, Kok). 
B(REYTENBACH), B. Lasarus. 1976. 'n Seisoen in die paradys. Johannesburg, Perskor.

BRINK, André P. 1962. 'n Kluit in die riet. Tydskrif vir letterkunde 12, 1:56-59.

BRINK, André P. 1980. Waarom literatuur? Intreerede. Grahamstad, Universiteit Rhodes.

BRÉE, Germain. 1964. Camus; a collection of critical essays. Englewood Cliffs, Prentice-Hall.

GUDDON, J.A. 1979. A dictionary of literary terms. London, Deutsch.

DEGENAAR, J.J. 1966. Die wêreld van Albert Camus. Johannesburg, APB.

DROS'TE, F.G. Het werkelijkheidsgehalte van literatuur. De Gids 1980(5):343-351.

ETCHELLS, Ruth. 1969. Unafraid to be; a Christian study of contemporary writing. London, I.V.F.

FOK KEMA, D.W. \& KUNNE-IBSCH, Elrus. 1978. Theories of literature in the twentieth century. London, C. Hurst.

GLICKSBERG, Charles I. 1966. Literature and the death of God. The Hague, Nijhoff.

GLICKSBERG, Charles I. 1972. Literature and society. The Hague, Nijhoff.

HENSEN, R. 1969. Evangelie en literatuur. (In: Grensgesprekken. Kampen, Kok). JAUSS, H.R. 1977. Geschiedenis en kunst. (In: W.J.M. Bronzwaer e.a. T'ekstboek algemene literatuurwetenschap. Baarn, Basis).

KAMER BEEK, J. 1964. Geschiedenis en problematiek van het begrip 'tijdgeest'. Forum der letteren V: 190-215.

KOHLSCHMIDT, Werner. 1965. Dichter, Tradition und Zeitgeist. Studien zur Literaturgeschichte. Bern, Francke.

KUMMER, E. 1979. Literatuur als ideologische interpretatie van de werkelijkheid. Forum der letteren 20(3):272-279, September.

KURRIS, F.J.M.G. 1967. Het beeld van het Christelijk geloof in hedendaagse romans. Vox theologica 37:106-117.

LOTMAN, Jurij M. 1977. Teksttypologie en de typologie van de tekstexterue verbanden. (In: W.J.M. Bronzwaer e.a. Tekstboek algemene literatuurwetenschap. Baarn, Basis).

LEBER, Hugo. 1966. Literatur als Spiegel der Zeit. Der Schweizer Buchhandel 24(12):417-424.

MARTHI, Kurt, LUTHI, Kurt \& VON FISCHER, Kurt. 1963. Moderne Literatur, Malerei und Musik, Stuttgart.

PINDER, Wilhelm 1961. Das Problem der Generation in der Kunstgeschichte Europas. München.

POPMA, K.J. 1966. Ethische Problemen in de moderne Literatur. Philosophia Reformala 31:50-67.

PUDER, Martin. 1971. Zur ästhetischen Theorie Adornos. Neue Rundschau 62(3): 465-477.

ROOKMAKER, H.R. 1966. Art and the public today. Ollon, L'Abri Fellowship. SARTRE, J-P. 1970. What is literature? Translated by Bernard Frechtman. London, Methuen.

STUTTER HEIM, C.F.P. 1963. Conflicten en grensen. Amsterdam.

STUTTER HEIM, C.F.P. $1966^{2}$. Problemen der Literatuurwetenschap. Amsterdam. 
SYPHER, Wylie. 1962. The loss of the self in modern art. New York, Vintage.

TEESING, H.P.H. 1952. Literatuurgeschiedenis en literatuurwetenschap. Groningen, Wolters.

TEESING, H.P.H. 1966. Periodiserung. (In Werner Kohlschmidt und Wolfgang Mohr. Reallexikon der deutschen Literaturgeschichte. Berlin).

TEESING, H.P.H. 1949. Das Problem der Perioden in der Literatuurwetenschap. Groningen, Wolters.

THIEME, Hans. 1968. Dichtung und Zeitgeschichte. Reformatio 17:104-112.

UNGER, Rudolf. 1929. Zur Frage geisteshistorischer Synthese, mit besonderer Beziehung auf Wilhelm Dilthey (In R. Unger. Aufsătze zur Prinzipienlehre der Literaturgeschichte. Berlin).

WIECHERT, Ernst. 1945. Der Dichter und die Zeit. Zürich, Artemis.

WIMSATT, W.K. \& BROOKS, C. 1957. Literary criticism - a short history. London, Routledgc \& Kegan Paul.

WIMSATT, W.K. 1964. The vrbal icon. Lexington, University Press.

WOLANDT, Gerd. 1972. Über die Rolle der Kunst. Zeilschriff für philosophische Forschung 26: 196-215.

YNTEMA, L. 1947. Ismen in de letterkunde. Philosophia Reformala 12:180-191. 